\title{
Oil Spills in the Arabian Gulf: A Case Study and Environmental Review
}

\author{
Nivine Issa ${ }^{1} \&$ Sreya Vempatti ${ }^{1}$ \\ ${ }^{1}$ Environment and Waste Division, AESG, United Arab Emirates \\ Correspondence: Nivine Issa, Environment and Waste Division, AESG, United Arab Emirates. E-mail: \\ n.issa@aesg-me.com
}

Received: May 1, 2018

Accepted: May 12, 2018

Online Published: May 29, 2018

doi: $10.5539 /$ enrr.v8n2p144

URL: https://doi.org/10.5539/enrr.v8n2p144

\begin{abstract}
The following article is a review of oil spills in the Arabian Gulf with a focus on the Kuwait Spill during the Gulf War. The article provides some background on the events leading up to the oil spill, as well as the extent and details of the spill. Impacts on air quality, terrestrial ecology, marine ecology, socioeconomic aspects, and public health are analyzed in detail to assess the extent of damage on various environmental and social components. It was found that significant impacts were incurred on the marine and terrestrial environments, with some negative effects still persisting to our present day. Heavy economic impacts were also incurred in the form of infrastructure damage and loss of productivity. The article further provides a review of various natural, mechanical, and chemical means of remediation utilized during the clean-up efforts and provides a relative comparison of these for potential usage on similar events in the future.
\end{abstract}

Keywords: Arabian Gulf, environmental impacts, marine contamination, oil spills, remediation.

\section{Introduction}

The Middle East is a transcontinental region adjoining countries in Western Asia, Europe, and North Africa. The Arabian Gulf is a part of this geographic region, and includes Oman, the United Arab Emirates, Qatar, Bahrain, Saudi Arabia, and Kuwait. Most of the countries around the Arabian Gulf have extensive reserves of crude oil and rely heavily on petroleum exports, making them more susceptible to spills and consequent marine pollution.

For decades, one of the common forms of pollution in the Arabian Gulf has been a combination of intentional and accidental oil spills in the marine environment due to anthropogenic activities. An oil spill is the release of crude oil or oil distilled products such as gasoline and diesel fuels to the environment causing land, water and air pollution. The causes of oil spills in the Arabian Gulf have varied from war related activities to accidental incidents related to oil tankers, offshore platforms, offshore drilling and spills and leakages from pipelines and ships.

The region has a number of especially sensitive environmental receptors including but not limited to extensive coral reefs supporting a number of commercially significant fish species, favorable habitats for migratory birds, extensive mangroves supporting a large number of marine species, seagrass beds supporting a number of endangered species in addition to sandy beaches supporting large populations of nesting Green and Hawksbill Turtles.

The extent of risks on coral reefs in the Arabian Gulf region is extensive (Figure 1: Reefs at Risk in the Middle East). Due to coastal development, overfishing and marine pollution, the coral reefs in this region are under significant pressure. The reefs of the Arabian Gulf are at critically high risk with over $85 \%$ of the existing coral reefs considered as threatened, as per the World Resources Institute.

As the socio-economic livelihood of many countries in the region is highly dependent on marine resources, marine pollution is integral to regional policies. The region's reliance on desalinated water for water supply in addition to the existing booming fisheries, coastal tourism and integrity of the marine ecosystem are just some of the key areas that are detrimentally affected by marine pollution incidents.

The Gulf War oil spill that took place in 1991 was the largest spill in history and was prompted by deliberately planned events that were war-related. Between August 1990 and February 1991, 460 million gallons of oil were 
spilled. The resulting oil slick extended for $65 \mathrm{~km}$ across the Kuwaiti and Northern Saudi coastline, and also contaminated 49 square kilometers of the Kuwait desert (Joyner \& Kirkhope, 1992).

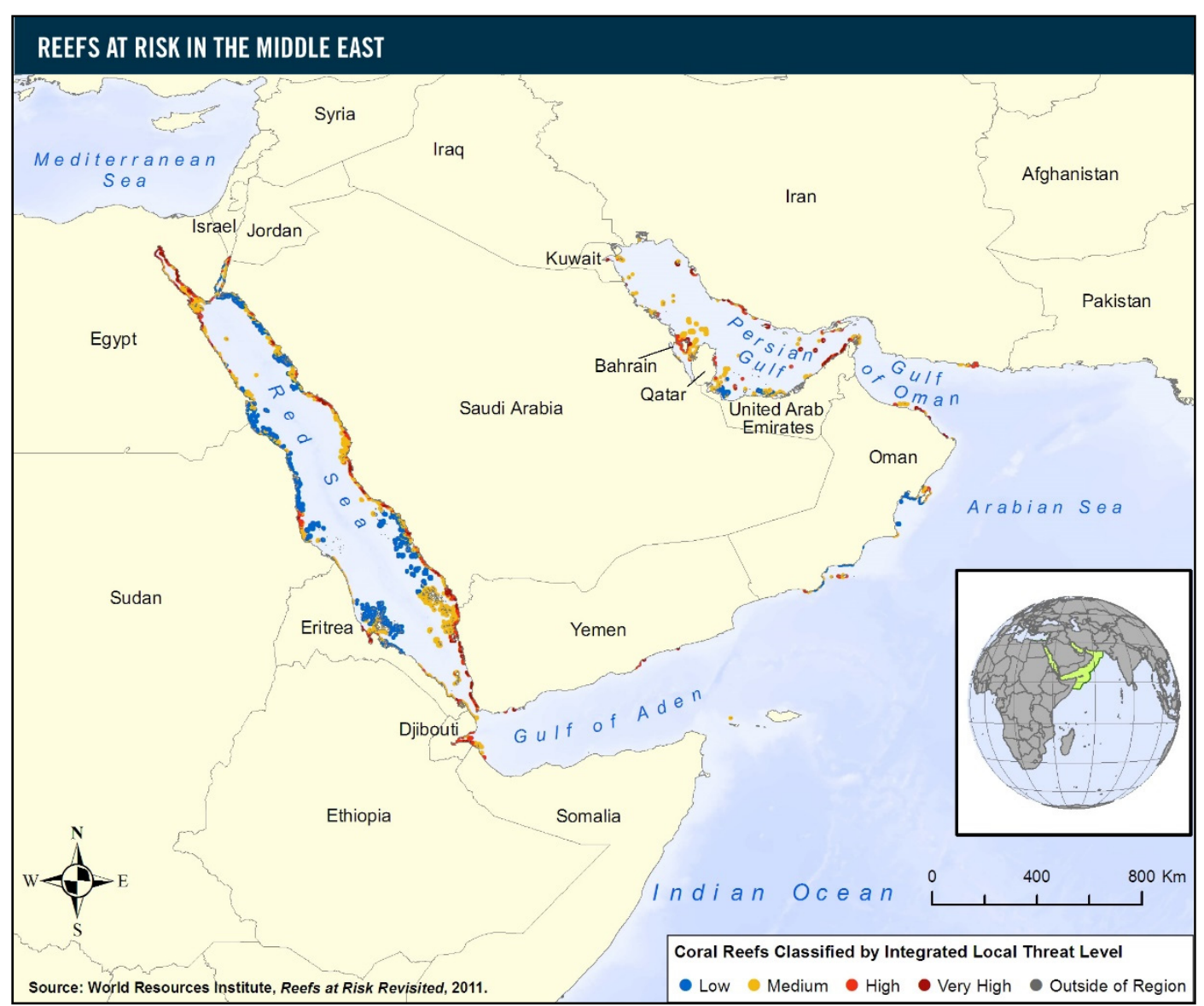

Figure 1. Reefs at risk in the Middle East

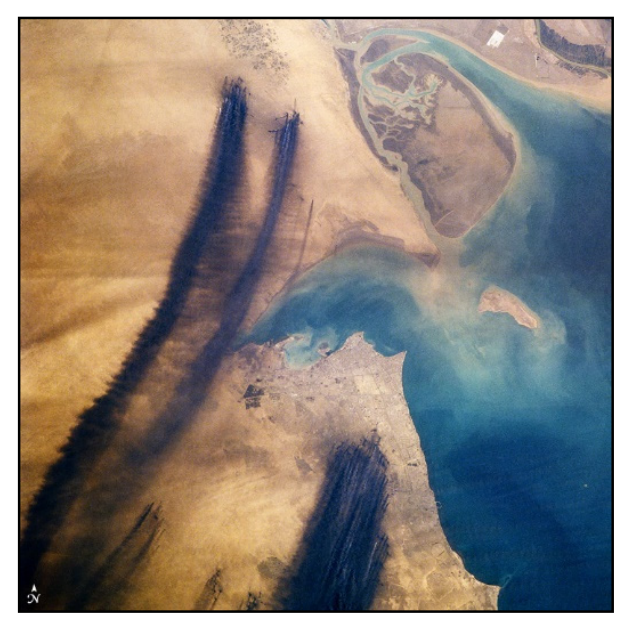

Figure 2. Satellite image showing plumes over Kuwait

This article aims to conduct a brief overview of the environmental and socioeconomic impacts that were incurred as a result of the Gulf War oil spill, including impacts arising from soil and groundwater contamination, air pollution, and socioeconomic changes. Various remediation techniques were utilized during the clean-up phase, 
including a combination of natural, mechanical, and chemical methods. These have been assessed in detail to provide insight into the process of managing and restoring the environment following large-scale oil spills.

\section{Environmental and Socioeconomic Impacts}

Oil spills are considered a large-scale event with significant ramifications on environmental health and human well-being. The marine environment, the terrestrial environment, public health and socioeconomic factors are all adversely harmed as a consequence of oil spills. This section will go into further detail on impacts associated with each major component, as well as specific impacts that occurred in the Arabian Gulf as a consequence of the Gulf War spill.

\subsection{Terrestrial Ecology}

Terrestrial ecological components are prone to multiple impacts that occur as a result of oil spills. In general, these include loss of productivity of the ecosystem, reduction in species composition, mortality of fauna as a result of being trapped in oil lakes, potential mortality due to accumulation of toxins, and changes in behavioral patterns due to changes in the surrounding environment.

In Kuwait, some notable effects on terrestrial ecology were observed as a result of the oil lakes and air pollution that formed. Adaptive changes were observed in both fauna and flora as a result of the environmental changes that occurred. There was an observed change in plant succession methods due to the lack of proliferation of certain species that were unable to thrive in the altered conditions. Similarly, fauna also exhibited behavioral changes. For example, the sand lizard (Acanthodactylus scutellatus) exhibited changes in the form of circadian rhythms, eating habits, and resting periods in areas that were affected by oil spills.

Several cases of mortality were recorded due to ingestion of oil. Fauna were reported trapped in oil lakes and several wildlife perished either due to poisoning or by suffocation. Toxic bioaccumulation was reported in some species and persisted for several years after the incident. Sand lizards (Acanthodactylus scutellatus) and ants were found to have elevated levels of polyaromatic hydrocarbons due to the presence of oil lakes and seepage into soil and groundwater. Flora also exhibited bioaccumulation effects, which led to elevated presence of heavy metals and hydrocarbons in certain species (Omar, Bhat, \& Asem, 2009).

\subsection{Soil and Groundwater}

Release of crude oil onto land has documented negative impacts on soil and groundwater. Pollutants such as benzene and polyaromatic hydrocarbons can have toxic effects on soil and groundwater quality when released into the soil. The resulting impacts can be significant and have wide ranging consequences.

In Kuwait for instance, airborne pollutants from smoke plumes from burning oil created an oil mist that covered $10 \%$ of the country's total surface area. Around half of the resultant soot was deposited within $100 \mathrm{~km}$ from the location of the incident. Large quantities of primary combustion products were released, including hydrocarbons, sulfur dioxide, nitrogen oxides, ozone, and volatile organic compounds. In addition, varying quantities of heavy metals and sodium chloride were also deposited on land. It has been found that the salt content of the soil has increased in areas up to $200 \mathrm{~km}$ away from the main incident (Linden \& Egerup, 2004).

Groundwater contamination was documented to have occurred immediately after the oil spill. Groundwater samples taken in 1993 indicated contamination, and oil lakes also contributed to groundwater deterioration. However, the extent of contamination appears to have dissipated with time. A recent study on hydrocarbon distribution in groundwater in Kuwait showed that 36 out of 42 wells were free of any noticeable pollutants, indicating that contamination had reduced considerably (Linden \& Egerup, 2004).

\subsection{Marine Ecology}

Marine habitats and species show varying responses to oil spills. Fish are negatively affected given that there is a possibility of directly ingesting oil through gills. This leads to biological responses such as reduced growth, changes in metabolic rates, and decline in reproductive success. Eggs and larvae are also negatively affected by spills. Evidence of marine vegetation deterioration varies. Some species exhibit die-offs, while other species such as algae and mangroves usually regenerate fairly rapidly depending on existing conditions (US Fish and Wildlife Service [USFWS], 2010). Similar to the effects on soil and groundwater, it is documented that oil spills also negatively affect marine water quality and sediment quality by increasing the concentrations of hydrocarbons and secondary pollutants.

Oil that washed up on beaches was found to have lost most of its toxicity. However, there were still many detrimental effects observed as a result of the slicks' physical properties. Oil slicks impacted marine vegetation by blocking light, thereby impeding effective exchange of air. The vast oil slicks that formed near the shoreline 
damaged vegetation along the shore due to temperature increases that formed as a result of the black colored surface's increased heat absorption. Oil slicks in some areas also hardened into tar and seeped into the subsurface, destroying several species and benthic habitats.

Most marine organisms in the Gulf usually breed during a transition period in the spring when there is a marked increase in sea water temperatures. Therefore, the oil spill and associated temperature increases due to smoke plumes would have likely had a deleterious effect on fish species in the area (Husain, 1995). Indeed, according to a study conducted by the World Conservation Monitoring Centre in 1991, fishing was impossible in heavily affected areas, and up to 10,000 tons of fish were found to be unsuitable for human consumption. Thousands of birds were affected along the Kuwaiti coastline. In particular, cormorants and grebes were heavily impacted; one study found that 30,000 birds of these species perished due to the formation of oil slicks on their feathers (Linden \& Egerup, 2004).

Mangrove communities were found to have incurred heavy damage as well. The Avicennia marina species is the only mangrove species found along the Saudi coast. Nearly half the mangroves in the affected area were damaged by the spill, and one-third died. However, natural regeneration did occur within two years. By 1995 , more than $90 \%$ of the pre-spill cover had been restored. Coral reefs are generally unaffected by oil spills. Given that oil accumulates on the surface of the water, it does not affect corals, which are located at a moderate depth from the surface. In Saudi Arabia, there was little to no evidence of damage to coral reefs following the spill. There was no significant impact on seagrasses either. This is likely due to the fact that oil accumulated on the surface instead of undergoing extensive mixing by wind or wave action (Poonian, 2003).

\subsection{Socioeconomic and Health Impacts}

Oil spills have been documented to have a wide range of impacts, including health impacts due to pollution, financial implications and decreased productivity due to infrastructure damages, as well as negative impacts on labor force availability and the fishing industry.

Health impacts were incurred due to air quality emissions that occurred from plumes and oil lakes. A survey conducted in Kuwaiti hospitals indicated an increased rate in respiratory diseases following the oil spill. Asthma levels were not significantly higher following the incident. Other health effects related to concentrations of pollutants such as sulfur dioxide and volatile organic compounds were also not recorded at significantly higher levels (Linden \& Egerup, 2004).

However, economic impacts borne by Kuwait were large-scale. The oil spill led to a loss of $1.5 \%$ to $2 \%$ of the country's total petroleum reserves, or the equivalent of $\$ 12.3$ billion to $\$ 38.4$ billion over the entire course of the nine-month war. Remediation measures required military assistance and thousands of machines from Kuwaiti troops and several other countries that participated in the efforts. The total cost of extinguishing oil spill-related fires has been estimated at more than $\$ 1.5$ billion. Infrastructure expenses related to reconstruction amounted to a further $\$ 6.5$ billion to $\$ 10$ billion between 1992-1995 (Shehabi, n.d.). There were negative implications for the labor force during the war as well. A large portion of the working population left the country, some by force and some by choice. Consequently, there was a shortage of both skilled and unskilled workers in various sectors (Shehabi, n.d.).

The fishing industry was strongly impacted due to air and marine pollution that arose as a result of the spill. The unfavorable temperatures and vast oil slicks resulted in a significant decrease in primary productivity as several fish and shellfish species were detrimentally affected. Additionally, damaged fishing equipment and infrastructure further compounded pressures on the fishing industry.

\subsection{Air Pollution}

Research conducted on air pollution arising from oil spills indicated differing results for pollution at the site when compared to pollution at the shore. It was found that hydrocarbons that evaporated from the oil slick constituted the largest source of primary air emissions. Once airborne, these soot emissions created secondary organic pollutants such as ozone and nitrates. A small portion is converted into microscopic particles, which can have significant health impacts when inhaled. The study concluded that hydrocarbons and associated secondary pollutants were confined to narrow plumes close to the site of the incident, whereas microscopic particles had the potential to travel much longer distances, potentially impacting the population along the coast (Middlebrook et al., 2012).

In the Kuwait oil spill incident, vast quantities of soot and gases were generated, which sank to the ground during inversions and still winds. Various types of smoke plumes were observed. These plumes were mostly found over the coastal part of Kuwait and the eastern regions of Saudi Arabia due to prevailing wind conditions. 
In total, more than 140 million metric tons of various hydrocarbons and secondary air pollutants were measured in the region.

An oil rain was formed, which later descended and contributed to the formation of several oil lakes. The oil lakes also contributed to air quality emissions, since they were a source of volatile organic compounds. Air quality research conducted showed that particulate matter was the main pollutant, and that all other pollutants were in lower quantities than anticipated. Various trace concentrations of heavy metals, polyaromatic hydrocarbons, and radionuclides were also measured (Linden \& Egerup, 2004).

\section{Response and Remediation}

Prevention and emergency preparedness are always preferred as, intervention and remediation, regardless of their effectiveness, are costly and complicated. For instance, the cleanup from the 1991 Gulf war has been estimated at approximately USD 700 million, and Kuwait is still dealing to this day with the reprimands of unignited oils dissipating into the ground, contaminating over 40 million tons of soil (Poonian, 2003). In the former case, Saudi Arabia was able to recover over a million barrels of oil using skimmer ships which selectively recovered and pumped the oil to storage, protecting its coastal infrastructure and maintaining oil production levels.

There are 5 phases of cleaning up marine oil spills as represented in Figure below:

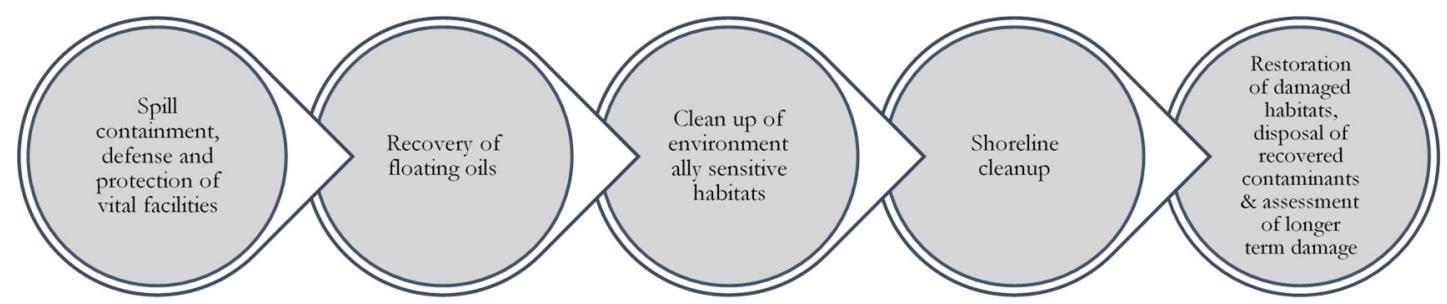

Figure 3. Phasing of oil spills clean up

The majority of the damage was done to the coastline of Kuwait and Saudi Arabia as well as a large stretch of the Kuwait desert, as a result of the deliberate actions executed by the Iraqi forces during the invasion. The primary clean-up efforts were concentrated on extinguishing fires, containing and recovering spilled oil, and pumping the oil into storage. Reports state that $95 \%$ of the oil was removed and recovered; the remaining $5 \%$ had formed large oil lakes as deep as 2 meters throughout the Kuwaiti desert, polluting soils and consequently precious groundwater reserves.

There is a number of cleanup and remediation techniques for managing oil spills; the efficiency of which is determined based on a number of factors such as the extent of contamination, existing conditions, availability of resources and sensitivity of the area. These management practices can be broken down into three categories: natural biodegradation, mechanical recovery and chemical treatment.

The following section explains the principle of each category and discusses the different techniques under each in addition to a brief assessment of their effectiveness in cleanup as well as the efficiency of their use in different scales of operation.

\subsection{Natural Biodegradation}

In some cases, taking no action could be the most feasible and practical way of dealing with the oil spill. For instance, some areas were left unmitigated after the Gulf war, and it had proven to be beneficial over time as extensive stretches of algae formed on the oil layers with the growth of organotrophic and cyanobacteria which are capable of utilizing crude oil as a source of carbon and energy as well as oxidizing the oil to their corresponding alcohols respectively. The natural degradation of the oils can be attributed to high temperatures, the intensive solar radiation, rapid bacteria growth and good marine flushing rates. This option's effectiveness and applicability however highly depends on many factors including the extent of contamination, the extent of the affected area and its environmental sensitivity, meteorological conditions and overall quality of the water.

In the case of the Gulf, many studies indicated that even though the Gulf waters were subjected to long term oil contamination, very little was found to have escaped to the Arabian Sea. Research showed that it was in fact due 
to the presence of naturally present microorganisms in the marine waters of the Gulf that the natural degradation of the oils occurred.

\subsection{Mechanical Recovery of Oil}

One of the primary and effective methods of responding to oil spills is through mechanical recovery. It is in fact one of the methods mostly used by governments around the world for cleaning up oil spills on different scales due to the various available designs dealing with different scales of operation, environmental conditions and oil types. There are different types of skimmers that can be used for the purpose of mechanically separating the oils from water and they are briefly explained hereunder (International Tanker Owners Pollution Federation Limited [ITOPF], 2014).

\subsubsection{Oleophilic Skimmers}

Oleophilic skimmers use materials that adhere to the oil as they rotate, then the oil is scraped off and allowed to be dropped into a sump from where it is pumped for storage. Oleophilic skimmers relatively have the highest recovery efficiency and they are most effective with oils of medium viscosity, but not as effective with less viscous oil products such as kerosene or diesel. Figure 4 shows a typical design of an oleophilic disc skimmer.

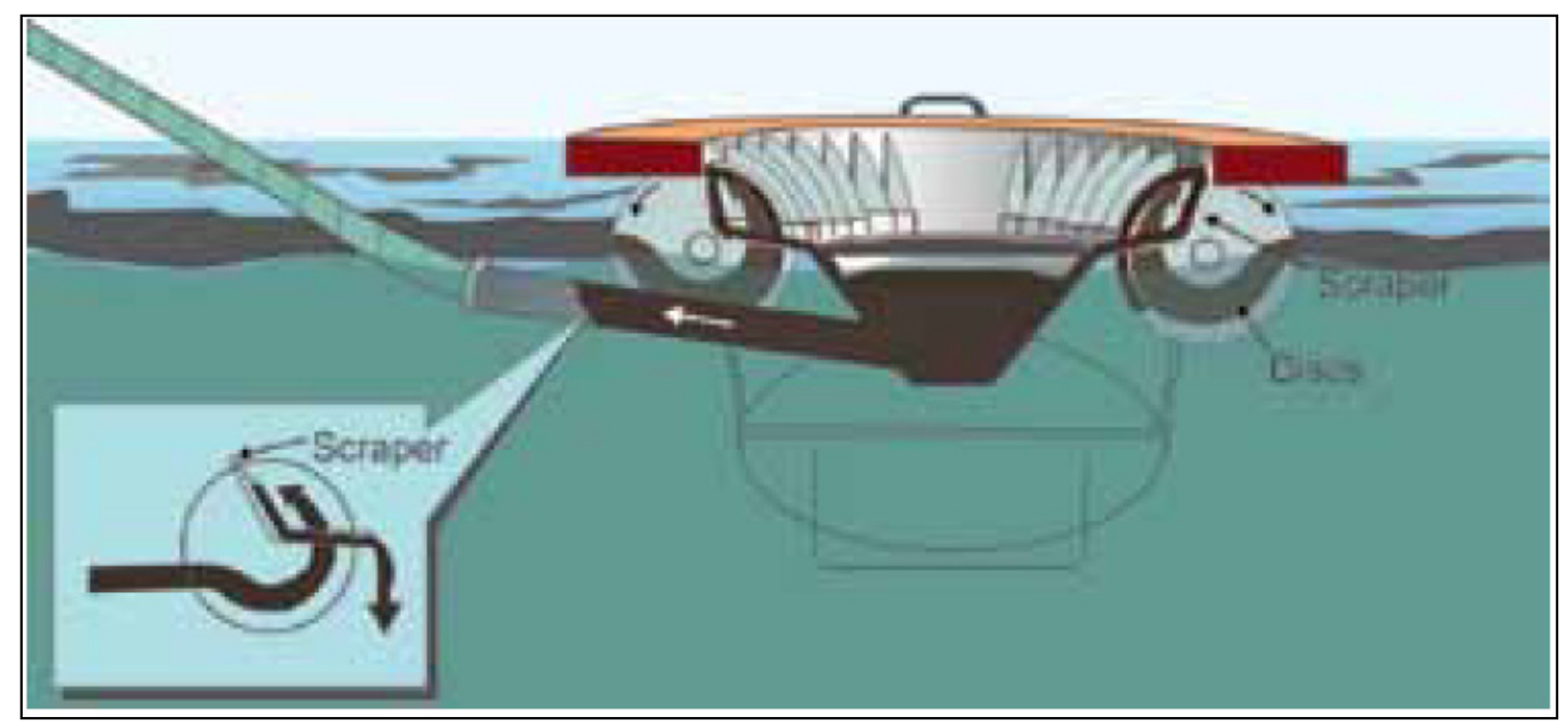

Figure 4. Typical design of an oleophilic disc skimmer

\subsubsection{Suction Skimmers}

One of the simplest designs to separate oils from water involves a suction device which physically pumps or suctions out the oil from the water surface. There are advantages and challenges to the use of suction skimmers and these are briefly presented in Table 1.

Table 1. Advantages and challenges of the use of suction skimmers

\begin{tabular}{ll}
\hline Advantages & Challenges \\
\hline $\begin{array}{l}\text { Widely available through vacuum trucks and trailers } \\
\text { (Figure ) }\end{array}$ & $\begin{array}{l}\text { Ideal for recovery of oil near the shoreline but limited applicability to more } \\
\text { offshore contamination sites }\end{array}$ \\
$\begin{array}{l}\text { There are portable vacuum systems which can facilitate } \\
\text { recovery from areas that are difficult to reach }\end{array}$ & $\begin{array}{l}\text { The challenge with this device is that storage of recovered oil is limited. } \\
\text { A fixed weir skimmer can be attached to a vacuum pump }\end{array}$ \\
$\begin{array}{l}\text { Placing a hose attached to a vacuum pump without a weir skimmer increases } \\
\text { A mesh screen can be used along with the suction hose }\end{array}$ & $\begin{array}{l}\text { Relatively high proportions of water is also consequently collected and it } \\
\text { onto floating oil to maximize recovery }\end{array}$ \\
\hline
\end{tabular}




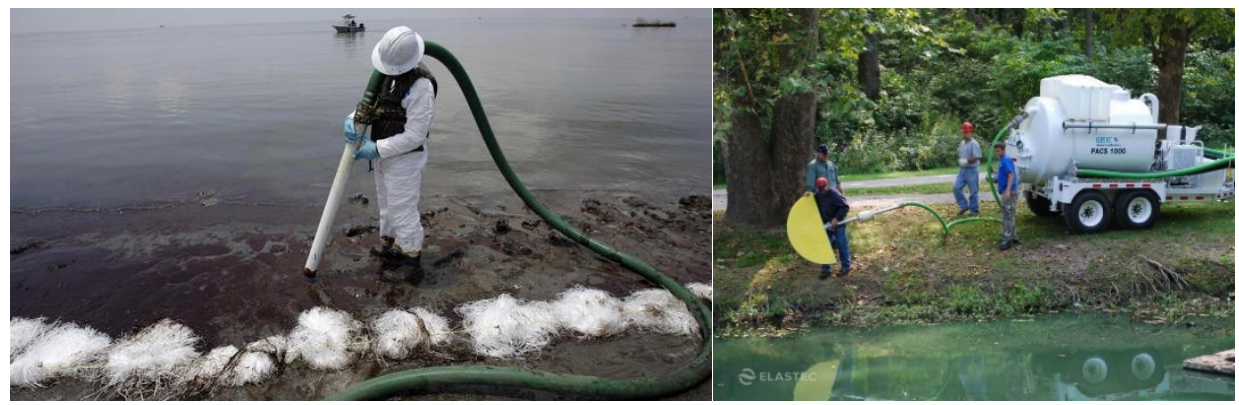

Figure 5. Portable oil vacuum device and truck suction skimmer with weir

\subsubsection{Weir Skimmers}

The concept of weir skimmers is that it uses gravity to selectively separate and trickle oil from the water surface. In most cases, weir skimmers are attached to oil suction/vacuum devices or machinery such as the truck suction skimmers with weir option mentioned earlier. The biggest challenge of using weir skimmers is its decreased efficiency in wavy conditions; however, many designs are now available in the market with improved efficiency. Some examples of weir skimmers include adding a belt adaptor to enhance the capability of the base weir skimmer in highly viscous oils and improvised options of weir skimmers through using plastic bottles and metal offcuts as shown in Figure 6. A traditional weir skimmer shown in Figure is best used in calm waters.
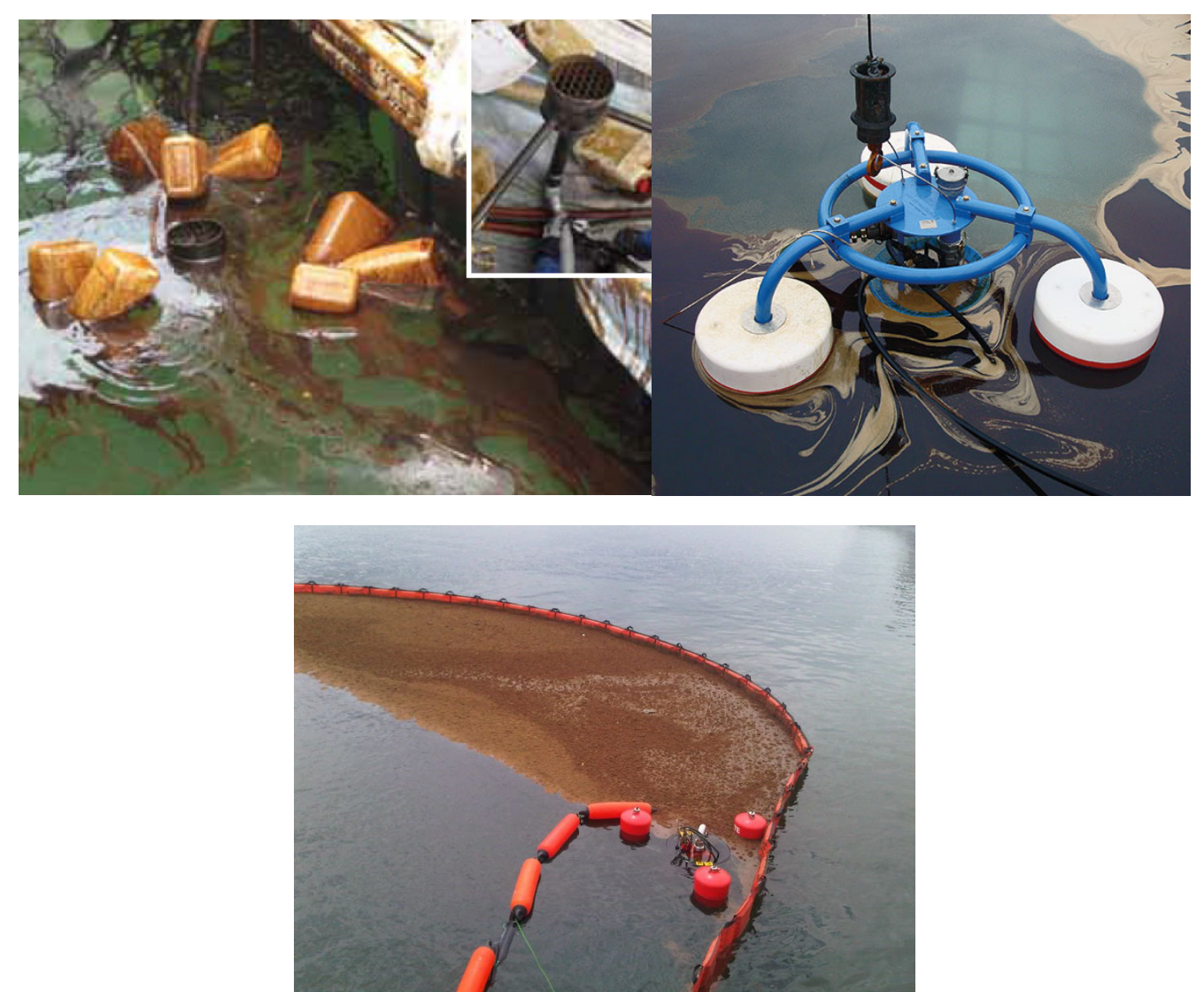

Figure 6. Standard oil weir skimmers (right), oil skimmer belt and booms (bottom) and improvised oil skimmer (left) 


\subsubsection{Other Skimmer Types}

There are other types of skimmers that are also available and they are adapted to an improved efficiency especially in wavy seas with rougher conditions. Upward rotating belts using oleophilic materials can be used by partially lowering them beneath the water to reduce the hinderance caused by the waves (Figure 7). Some designs also involve the use of buckets or paddles on the belt itself to help with the physical separation of the oil from the water.

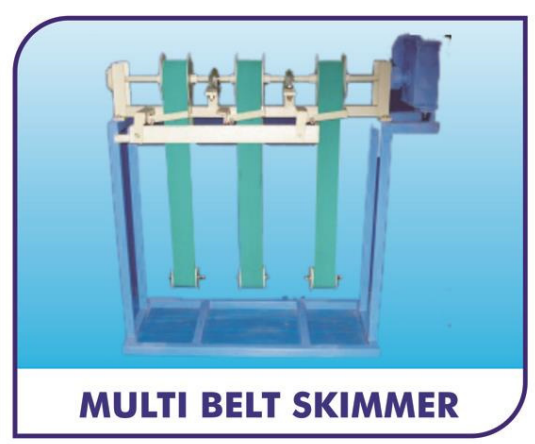

Figure 7. Skimmer with rotating belt

\subsection{Chemical Remediation}

Chemical response to oil spills is undertaken with the aim of chemically dispersing the oil from sensitive areas or collecting it in thicker densities. As such, chemical treatment techniques are always combined with a subsequent physical removal using mechanical techniques.

Chemical absorbents are used through spraying them on the spilt oils to allow for better mechanical collection.

Two types of chemical absorbents are used for the chemical remediation of oil spills in marine ecosystems: dispersants and solidifiers. Dispersants are surface active agents that are capable of breaking down the slick of oil into smaller droplets, as illustrated in Figure8. Solidifiers are dry granular compounds that are capable to react with oil and transform it into solid rubber that can be easily removed through mechanical techniques (Dave \& Ghaly, 2011).

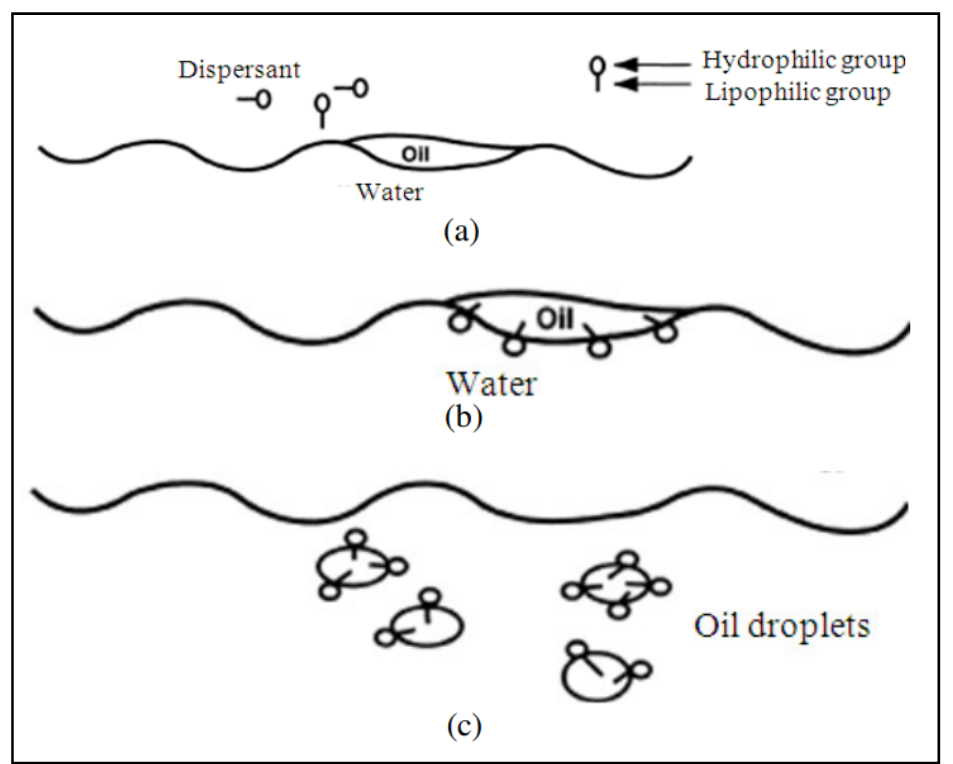

Figure 8. Mechanism of oil remediation using dispersants 
Table 2 provides a brief assessment of both types of chemical agents used in oil spill remediation.

Table 2. Dispersants versus solidifiers

\begin{tabular}{lll}
\hline & Dispersants & Solidifiers \\
\hline Application & $\begin{array}{l}\text { Used by spraying them onto the water and mixing } \\
\text { them either by boat or wind }\end{array}$ & $\begin{array}{l}\text { Applied in various forms (dry particulates and semi solid } \\
\text { materials contained in booms, pillows, pads... }\end{array}$ \\
$\begin{array}{l}\text { Conditions } \\
\text { optimal efficiency }\end{array}$ & $\begin{array}{l}\text { Best used during high winds and rough seas and } \\
\text { when mechanical recovery is not possible }\end{array}$ & $\begin{array}{l}\text { Best used on moderately rough seas allowing better } \\
\text { mixing hence better solidification }\end{array}$ \\
& Capable of treating 90\% of spilled oil and are less & Lower efficiency than dispersants, and have not been \\
costly than physical methods & extensively used \\
& $\begin{array}{l}\text { Inflammability causing health hazards during } \\
\text { application and damage to marine life }\end{array}$ & $\begin{array}{l}\text { Recovery of oil after solidification is challenging due to } \\
\text { the large amount require (16 to 200\% of oil mass) }\end{array}$ \\
\hline
\end{tabular}

\subsection{Other Remediation Techniques}

Other means have been used around the world for the remediation of oil spills and these include thermal remediation and bioremediation.

Another viable option would be viable implemented during the cleanup efforts after the Gulf war involves burning the oils when they are still in high concentrations. This does not pose significant risk to animal and plant life (Lovell, 1998). This process, known as thermal remediation, employs in-situ burning of the oil to effectively remove spilled oil and jet fuel. It is mostly effective in calm weather conditions on oils that are highly flammable to quickly burn while causing minimal damage to marine life. Even though effective in removing a substantial amount of oil when applied directly after a spill has occurred, other concerns arise such as the risk of causing secondary fire, human health hazards and environmental pollution caused by the burning byproducts.

Bioremediation is the process of using microorganisms to degrade chemical substances and bring environmental quality back to its original state. Both bacteria and fungi can be used for the degradation of hydrocarbons but bacteria are more commonly used. The different bacteria that have been reported efficient in degrading hydrocarbons include Pseudomonas, Achromobacter, Acinobactor, Alcaligenes, Arthrobacter, Bacillus Brevibacterium, Cornybacterium, Flavobacterium, Nocardia, Pseudomonas, Vibrio (Dave \& Ghaly, 2011). However, there are challenges associated with this process as well. Bioremediation is limited to compounds that are biodegradable, and if the process is not carried out successfully, further contamination could occur due to the proliferation of unwanted by-products that have not been properly broken down.

\section{Conclusion}

The Arabian Gulf region, having the world's largest oil reserves, is most prone to oil spills in marine and terrestrial environments. Historically, oil spills of varying scales have occurred in the region caused by both conflicts of war and accidental incidents. Among the world's largest oil spills was the Kuwait oil spill, which occurred in the early 1990s due to war-related events.

Oil spills of varying scales can cause detrimental impacts on various environmental components such as soil, groundwater, terrestrial and marine ecology, marine quality and air pollution. In addition, the cost of oil spill cleanup and remediation can be very steep; countries in the Arabian Gulf are still dealing with the repercussions of the Gulf War oil spills to this day.

There are numerous clean up and remediation strategies. These can be categorized as natural, mechanical, chemical, and biological, all of which have been discussed in this article. The choice of clean-up technique is determined based on the extent of pollution, the sensitivity of the project area and the availability of resources, with some mechanical and bioremediation techniques being up to $95 \%$ effective in the removal and recovery of oils.

\section{References}

Dave, D., \& Ghaly, A. E. (2011). Remediation Technologies for Marine Oil Spills: A Critical Review and Comparative Analysis. America Journal of Environmental Sciences, 7(5), 423-440. https://doi.org/10.3844/ ajessp.2011.424.440

Husain, T. (1995). Kuwaiti Oil Fires: Regional Environmental Perspectives (1st ed.). Great Britain: Elsevier Science Limited. 
Joyner, C. C., \& Kirkhope, J. T. (1992). The Persian Gulf War Oil Spill: Reassessing the Law of Environmental Protection and the Law of Armed Conflict. Case Western Reserve Journal of International Law, 24(1).

Kostreba, L. (1999). Oil Spill Remediation Efforts in the Middle East. Restoration and Reclamation Review, Student Online Journal, Department of Horticulture Science, University of Minnesota, 3(4).

Linden, O., Jernelov, A., \& Egerup, J. (2004). The Environmental Impacts of the Gulf War 1991 (Working paper No. IR-04-019). Retrieved from http://pure.iiasa.ac.at/id/eprint/7427/1/IR-04-019.pdf

Lovell, J. (1998). The Threat of International Oil Spills to Desalination Plant in the Middle East. Air Command and Staff College, Alabama.

Middlebrook, A. M., Murphy, D. M., Ahmadov, R., Atlas, E. L., Bahreini, R., Blake, D. R., ,.. Ravishankara, A. (2012). Air Quality Implications of the Deepwater Horizon Oil Spill. Proceedings of the National Academy of Sciences, 109(50), 20280-20285.

Omar, S. A., Bhat, N., \& Asem, A. (2009). Critical Assessment of the Environmental Consequences of the Invasion of Kuwait, the Gulf War, and the Aftermath. Handbook of Environmental Chemistry, 141-170. https://doi.org/10.1007/978-3-540-87963-3_5

Poonian, C. (2003). The Effects of the 1991 Gulf War on the Marine and Coastal Environment of the Arabian Gulf: Impact, Recovery and Future Prospects (Unpublished master's thesis). King's College London, UK.

Shehabi, M. R. (n.d.). An Extraordinary Recovery: Kuwait Following the Gulf War (Working paper No. 15.20). Retrieved from http://www.business.uwa.edu.au/_data/assets/pdf_file/0006/2765850/15.20-Shehabi, -M.-An-Extraordinary-Recovery-Kuwait-Following-the-Gulf-War.pdf

Tawfiq, N. I., \& Olsen, D. A. (1995). The Role of International Cooperation During Saudi Arabia's Response to the 1991 Arabian Gulf Oil Spill. Paper presented at the Petroleum Association Japan Symposium.

The International Tanker Owners Pollution Federation (ITOPF). (2014). Use of Skimmers in Oil Pollution Response: Technical Information Paper. Retrieved April 29, 2018, from http://www.itopf.com/ knowledge-resources/documents-guides/document/tip-5-use-of-skimmers-in-oil-pollution-response/

U.S. Fish, \& Wildlife Service. (2010) Effects of Oil on Wildlife and Habitat. Retrieved from https://www.fws.gov/home/dhoilspill/pdfs/DHJICFWSOilImpactsWildlifeFactSheet.pdf

Volkman, J., \& Revill, A. (2006). Oil Pollution and Microbial Regulation. Environmental and Ecological Chemistry, (2).

\section{Copyrights}

Copyright for this article is retained by the author(s), with first publication rights granted to the journal.

This is an open-access article distributed under the terms and conditions of the Creative Commons Attribution license (http://creativecommons.org/licenses/by/4.0/). 